\title{
Türkiye'de ve Dünyada Teratojenite Bilgi Servislerinin Çalışma Koşulları ve Sağladıkları Hizmetler
}

\author{
Working Conditions and The Services Provided of Teratogenicity \\ Information Services in Turkey and The World
}

\author{
Ayçe ÇELİKER ${ }^{1^{*}}$ \\ Orcid : 000000016753 6844, \\ Merve GÖÇER ${ }^{2}$ \\ Orcid : 0000000268979206
}

${ }^{1}$ Hacettepe Üniversitesi Eczacılık Fakültesi- Klinik Eczacılık Anabilim Dal1- Ankara- Türkiye

${ }^{2}$ Yüreğir Devlet Hastanesi-Serinevler Mahallesi, Ege Bagatur Blv. No: 236, 01240, Yüreğir-Adana- Türkiye

\section{Corresponding author:}

Ayçe ÇELIKERR

Hacettepe Üniversitesi Eczacıllk Fakültesi

Klinik Eczacilık Anabilim Dalı

Eczacılık Fakültesi Ek Yerleşke- Giriş Katı

Altındağ- 06100-Ankara- Türkiye

Tel: 0312-305 21 33, 05324004076

E posta: aycelike@hacettepe.edu.tr

aycelike@hotmail.com

\section{ABSTRACT}

The frequency of drug use during pregnancy and increased drug diversity increased the risk of teratogenicity. Since ethical reasons complicates the process of obtaining and evaluating the correct information in pregnant women, the collection regularly and protection carefully of obtained data is of utmost importance. Studies on these data should be conducted, and pregnant women and physicians should be guided by this information. The anxiety that started in pregnant women and physicians after the thalidomide disaster experienced in the 1960s caused a need for counseling more detailed and this process resulted in the establishment of teratology information and/or counseling services. These services have increased considerably in terms of number and have improved in terms of functioning. The aim of this review is to submit a compilation related to the literature regarding the history, working conditions and services they provide of Turkish and the world teratogenicity consultancy services.
\end{abstract}

Keywords: Teratogenicity, drug counseling during pregnancy, teratogenicity counseling services, OTIS, ENTIS

\section{ÖZET}

Gebelikte ilaç kullanımının sıklığı ve ilaç çeşitliliğin artması teratojenite riskini artırmıştır. Etik nedenler gebelerde doğru bilgi edinme ve değerlendirme sürecini zorlaştırdığı için elde edilen verilerin düzenli bir şekilde toplanması ve dikkatli bir şekilde korunması çok büyük önem taşımaktadır. Bu veriler üzerinde çalışmalar yapılmalı, gebelere ve hekimlere bu bilgiler ışığında yol gösterilmelidir. 1960'larda yaşanan Talidomid faciası sonucunda gebelerde ve hekimlerde başlayan kaygı, daha ayrıntılı bir danışma ihtiyacı doğurmuş ve bu süreç teratoloji bilgi ve/veya danışma servislerinin kurulmasıyla sonuçlanmıştır. Bu servisler sayıca bir hayli artmış ve işleyiş yönünden de gelişmiştir. Bu derlemenin amacı Türkiye ve dünyadaki teratojenite danışma servislerinin tarihçeleri, çalışma koşulları ve sağladıkları hizmetler ile ilgili literatür taramaları aracılığıla edinilen bilgileri sunmaktır.

Anahtar Kelimeler: Teratojenite, gebelikte ilaç danışmanlığı, teratojenite danışma servisleri, OTIS, ENTIS 


\section{Giriş}

Gebelikte ilaç kullanımı oldukça yaygındır. Amerika Birleşik Devletleri (ABD)'nde hamile kadınların $\%$ 90' ından fazlasının bu dönemde en az 1 reçeteli ve/veya reçetesiz ilaç kullandığı ve ilaç kullanımının $\%$ 80' inden fazlasının ilk trimesterde gerçekleştiği gösterilmiştir [1]. Bu oranın yüksekliği planlanmamış gebeliklerin yanı sıra, gebeliğin başlangıcında kadının gebe olduğunu bilemeyeceği bir dönemin olmasından da kaynaklanmaktadır [2]. Kullanılan farklı türlerdeki ilaçların sayısı da dönemlere göre değişiklik göstermekte olup 1970'lerde ortalama 2,5 iken, 2000'lerin başlarında 4,2'ye yükseldiği bildirilmiştir [3]. Ülkemizde gebelikte kullanılan ilaçlar konusunda yapılan çalışmalara göre, en sık kullanılan ilaç grupları; antibiyotikler, analjezikler, antidepresanlar ve antigriballer olarak sıralanmaktadır [4].

$\mathrm{Bu}$ artışlar sonucunda maruziyetlerin hamilelikteki etkileriyle ilgili sorunlar yaygınlaşmıştır. Bu sorunlar genellikle hekimler, eczacılar, genetik danışmanlar, zehir kontrol merkezleri ve ilaç bilgi merkezlerinde çalışan uzmanlar dahil olmak üzere çeşitli eğitimlere sahip sağlık görevlileri tarafindan ele alınmaktadır [5]. Yine ülkemizde yapılan bir çalışmaya göre anne adayları ilaç kullandıkları için danışmanlık almak üzere büyük çoğunlukla (\%85) ilk trimesterde hekime/eczacıya başvurmakta, 2 . ve 3 . trimesterdeki başvurular düşük oranda kalmaktadır (sırasıyla \%14 ve $\% 0,7)$. [4]

İlaç kullanımı anne, bebek veya her ikisi üzerinde geçici veya kalıcı ciddi sorunlar oluşturabilmektedir. $\mathrm{Bu}$ nedenle, hamilelik ve öncesi bakım önem kazanmakta ve danışmanlık gerekli hale gelmektedir [6]. Ancak gebelerin etik nedenlerden dolayı randomize klinik çalışmalarda yer alamaması, ilaçların onaylanma sırasındaki olası teratojenik riskleri konusundaki bilgileri sınırlamaktadır. Kanıta dayalı bilgileri derlemek, hamilelere ve hekimlere bu bilgileri en güncel ve tarafsız şekliyle sunarak olası teratojenik etkilerin önüne geçmek amacıyla teratoloji danışma servisleri kurulmuştur [1].

$\mathrm{Bu}$ derlemenin amacı, literatür taramaları aracılı̆̆ıyla, Türkiye ve dünyadaki teratojenite danışma servislerinin tarihçeleri, çalışma koşulları ve sağladıkları hizmetler ile ilgili bilgileri sunarak ilgili sağlık görevlilerinde konuya ilişkin farkındalık oluşturmaktır.

\section{Teratojenite İle İlgili Terminoloji}

“Teratojenite" gelişimsel toksisitenin bir belirtisi olup, yavruda yapısal bozuklukları tetiklemek veya sikl1ğını artırmak suretiyle embriyo / fetotoksisiteye yol açan özel bir durumu temsil eder [7]. "Teratojen" ise oluşan kusurlara yol açan etkenin kendisi olarak tanımlanmaktadır. Sözcük, Yunanca "canavar, korkunç gözüken" gibi anlamlar içeren "teraton / teratos"dan türemiştir [7, 8] "Teratoloji”" de, anormal prenatal büyümeye çevrenin katkılarının yanı sıra morfolojik veya fonksiyonel gelişimsel kusurları inceleyen bilim dalıdır [9]. Teratojenler çevresel ajanlar olup fiziksel (X- 1şınları, hipertermi), kimyasal (ilaçlar, pestisitler, ağır metaller vb.), enfeksiyöz (kızamıkçık virüsü, zika virüsü vb.) ya da maternal hastalık veya durumlar (diyabet, preeklamsi vb.) şeklinde sınıflandırılabilir $[9,10]$.

Teratojenlerin fetüs üzerindeki etkileri makro veya mikro düzeyde olabilir. Bu etkiler düşük (abortus), büyüme ve gelişme bozuklukları, organlarda morfolojik bozukluklar, intrauterin gelişimde gecikme, prematüre doğum, fetal ölüm, zihinsel gelişimde gecikme, fizyolojik fonksiyonlarda bozukluk (körlük, sağırlık vb.), kanser oluşumu, erken veya geç olgunlaşma ve genetik değişim olarak gelişebilir. Özgül anomaliler veya sendromlar da teratojenik özgül etkiler arasındadir. [9]

Klinik teratolojinin temel amaçları, dış kaynaklı etkenlerin neden olduğu doğum öncesi gelişim bozukluklarını önlemek ve istenen gebeliklerde ilaçlara veya diğer olası teratojenlere maruz kalma riskinin fazla olmasına bağlı olarak gözlenen kaygıyı, tedaviye uyunçsuzluğu, gereksiz girişimsel tanı uygulamalarını azaltmaktır [11].

Konuyla ilgili diğer bir terim de "intrauterin gelişmedeki yapısal bir soruna bağlı olarak organlarda veya vücudun bölümlerinde ortaya çıkan kusurlar" şeklinde tanımlanan "malformasyon"dur [12]. Malformasyonlar, yaşamın sürdürülmesinin olanaksız ya da çok zor olduğu majör malformasyonlar (örneğin yaşamın sürdürülmesinin olanaksızlaştığ fali veya düzeltilmesi için büyük bir cerrahi girişim gereken konjenital kalp hastalığ 1 ya da mental retardasyon gibi ciddi bir işlev bozukluğu) ya da daha küçük müdahalelerle yaşamın sürdürülebildiği minör malformasyonlar (fazla parmak oluşumu gibi) olarak sınıflandırılabilir [13]. Malformasyonlu doğumların yaklaşı \% 65-75'inin etiyolojisinin bilinmediği, 10$\% 25^{\prime}$ 'inin genetik özelliklere bağlı olduğu, \%10'unun 
ise ilaçlar dahil olmak üzere çeşitli çevresel etkenlerden kaynaklandığı bildirilmektedir [14].

Etkenlerin fetüs üzerindeki toksik etkisi ilacın türüne ve maruz kalınan gebelik dönemine göre değişiklik göstermektedir. Erken gebelik ya da "preimplantasyon"döneminde (1 - 2. hafta) maruziyette ya gebelik abortusla sonlanır ya da herhangi bir etki görülmez ("ya hep ya hiç kuralı") [15]. Son adet tarihinden itibaren 5-10. haftalar arası organ oluşumu (organogenez) dönemi olup teratojen ajanlara duyarlılık en yüksek düzeydedir [8]. Organogenezi izleyen dönem "fetal gelişim" dönemi olup fizyolojik ve fonksiyonel olgunlaşma gerçekleşir. Fetal dönemdeki teratojenlere maruziyette ise minör malformasyonlar, büyüme geriliği ve fonksiyonel bozukluklar görülür [15].

Teratojenik etkisi olduğu kesin olarak bilinen ilaç sayısının çok az olmasına karşın (talidomid, valproik asit, alkol, retinoidler, vb...), teratojenitesi ile ilgili veri olmayan veya çok az veri bulunan ilaç sayısı oldukça fazladır [11]. Ayrıca her yıl ilaç endüstrisi embriyofetal etkileri bilinmeyen ve bu yüzden gebelik sırasında kullanılması önerilmeyen çok sayıda ilacı piyasaya sürmekte, dolayısıyla yeni ilaçlarla ilgili teratojenite bilgisi yetersiz olmaktadır. Etik nedenlerle insanlar üzerinde teratojenite çalışmaları yapılamazken, veriler deney hayvanları üzerindeki çalışmalar ve klinik gözlemlerle sınırlı kalmaktadır. Sonuç olarak da ilaçların teratojen etkileri konusundaki bilgi açığı giderek artmaktadır.

Teratojenik etki sonucu ortaya çıkan kusurun oluşumuna katkıda bulunan gebeyle ilgili etkenler arasında kalıtımsal ve fizyopatolojik özellikler, metabolik özellikler (diyabet, obezite, vb.), radyasyon veya mikrobiyolojik etkenlere maruziyet, bölgesel ve etnik özellikler, yaş, kilo, beslenme, sosyo-ekonomik düzey bulunmaktadır [16]. İlaca ilişkin özellikler ise ilacın yapısı, dozu, alınma sıklığı, plasentaya geçişi, dağılımı, metabolizması, eliminasyonu, başka ilaç ya da maddelerle etkileşimidir. Bazı durumlarda malformasyonlar (anestezik olarak kullanılan kokainin vazokonstriksiyon yaparak distal bir organda sekonder atrofiye neden olması gibi), ikincil etki olarak gelişebilmektedir [9].

İlaçlar kimyasal yapılarına veya etki mekanizmalarına göre teratojenik etki göstermektedir. Örneğin cinsiyet hormonları daha çok ürogenital sistem anomalilerine, antimetabolitler ise DNA'yı etkileyerek sitotoksik etkilere yol açmaktadır [15].
Özgül bir malformasyon için, söz konusu organın oluşum dönemi dikkate alınmalıdır. Örneğin, yarık damak gestasyonun 12-14., hipospadias ise 14-16. haftaları arasında ortaya çıkmaktayken, inmemiş testisin kritik dönemi 7-9. ve patent ductus arteriosusunki ise 9-10. haftalardır [17].

Günümüzde kullanımının giderek yaygınlaştığı görülen bitkiler ve/veya bitki ekstrelerinin oral yolla kullanılan (nutrasötik) ya da topik olarak uygulanması amacıyla hazırlanmış olan (kozmesötik) ürünlerinin, gebelik dönemindeki etkilerine ilişkin çalışmalar çok yetersiz olup bazıları gebeliğin sağlıklı ilerlemesini tehdit eden etkenler arasinda yer almaktadır [18]. Bu konuda Alman E Komisyonu (Almanya Bitkisel İlaçları Ruhsatlandırma Dairesi) ve Avrupa İlaç Ajansı (European Medicines Agency = EMEA) var olan çalışmaları inceleyerek güvenlik ve etkinlik değerlendirmesi yapılan monograflar yayınlayan referans merkezleri olarak öne çıkmaktadır $[19,20]$.

\section{Gebelik Döneminin Fizyolojik Özellikleri}

Hamilelik sırasında ilaçların farmakokinetiğini ve farmakodinamiğini etkileyebilecek fizyolojik değişiklikler aşağıda sıralanmıştır [21]:

a. Toplam vücut ağırlığı ve vücut yağ bileşimindeki değişiklikler,

b. Mide motilitesinde azalmaya bağlı biyoyararlanım değişiklikleri,

c. Artan plazma hacmi, hücre dışı sıvı ve toplam vücut suyu oranı,

d. Plazma albümin konsantrasyonunda azalma,

e. Artan glomerüler filtrasyon hızı,

f. Karaciğer enzim aktivitesindeki değişiklikler.

Fetüsün kan-beyin engelinin geçirgenliği yetişkinlerdekinden yüksek, karaciğerin detoksifikasyon işlevi ise daha az etkin olduğundan ilaçlara bağlı toksisite gelişmesi olasılığı daha yüksektir. Gebelik ilerledikçe fetüs böbreklerinin işlevi artar ve hidrofilik ilaçlar hızlı bir şekilde elimine edilebilir [22].

Hamilelik sırasında gerektiğinde kan düzeyini izlemek ve/veya uygun doz ayarlamaları yapmak zorunlu hale gelebilir. İlaç kullanımının risk/yarar dengesi bireyselleştirilmiş bakım temelinde değerlendirilmelidir. 
Tedavi edilmeyen kronik hastalıklar da gebelik sonuçlarını olumsuz etkileyebilir hatta kendileri teratojenik etkilere yol açabilir. Birçok kadın astım, epilepsi, hipertansiyon, migren, hipotiroidizm ve diyabet gibi kronik hastalıklar için tedavi edilmekteyken gebe kalmaktadır. Bu tanılar kontrol altında tutulmazsa ciddi komplikasyonlarla karşılaşılabilir. $\mathrm{Bu}$ nedenle, ilacın anneye yararı / fetüs için riski oranının belirlenmesi önemlidir [23].

Birçok sağlık uzmanı hamilelik ve öncesinde bazı besin destek ürünlerini (folat, demir ve kalsiyum) önermekte ise de, çok sayıda besin destek ürününün güvenliliği ve etkinliği kanıtlanmamıştır. ABD'de prekonsepsiyonel bakım önerileri arasında gebelik öncesinde hepatit B ve kızamıkçık aşılarının yapılması, sigara ve alkolün kesilmesi, maternal fenilketonürinin kontrol altına alınması ve edinilmiş bağışıklık yetmezliği sendromu (AIDS) taramalarının ihmal edilmemesi yer almaktadır [24]. Bazı ülkelerde resmi sağlık otoritesi tarafından gebelik döneminde kontrendike olan ilaçların listeleri yayımlanmakta ve ilaçlar ya kesin kontrendike olarak ya da maternal yarar/fetal risk çerçevesinde izin verilebilecek ilaçlar şeklinde sınıflandırılmaktadır [25].

\section{Uluslararası Kuruluşların Teratojenite ile ilgili Çalışmaları}

\subsection{Dünya Sağlık Örgütü}

1961 yılında Talidomid faciasından sonra ABD'de başlayan uygulama ile, ruhsatlı ilaçlara ilacın etkinliği kadar güvenliliğini de kantlama zorunluluğu getirilmiştir. 1968 y1lında düzenlenen 16. Dünya Sağlık Kurulu sırasında alınan kararlar doğrultusunda Dünya Sağlık Örgütü (DSÖ) Uluslararası İlaç İzleme Programı oluşturulmuştur. Aynı yıl İngiltere'de gündeme gelen "Sarı kart" uygulaması sonrasında hazırlanan Avrupa Birliği genelgesi ile ilgili olarak, DSÖ uluslararası ilaç izlemine başlamıştır. DSÖ, ulusal merkezlerin farmakovijilans çalışmalarını değerlendirme ve koordinasyonu için özel kılavuzlar, yöntemler ve algoritmalar geliştirme çalışmalarının, uluslararası platformlar ve uzman komiteler kurmalarının desteklenmesini önermektedir [8].

\subsection{Konjenital Anomaliler ve Ikizler $\ddot{U} z e r i n e$ Avrupa Ortak Eylemi (EUROCAT)}

Avrupa Konjenital Anomaliler ve İkizler Üzerine Avrupa Ortak Eylemi (European Concerted Action on Congenital Anomalies and Twins = EUROCAT) Avrupa'daki nüfusa dayalı konjenital anomali kayıtları ağı olup 1979'da kurulmuştur ve Avrupa Birliği tarafindan finanse edilmektedir. 1981 itibariyle, 10 Avrupa ülkesinden yaklaşık 200.000 doğumu kapsayan 17 kaydın aktif olarak EUROCAT'a rapor verdiği bildirilmiştir. Kayıtlar iyi tanımlanmış bir popülasyonda belirli bir hastalığın tüm olgularını kapsamlı ve sürekli olarak toplayan ve kaydeden bilgi sistemleri olarak tanımlanmaktadır [26]. 2021 itibariyle Türkiye'nin yer almadığı bu liste, 76 ülkenin katılımıyla oluşan iyi bir ağ haline gelmiş olup 82 konjenital anomali alt grubu hakkında yaygın bir şekilde kullanılan veriler sağladığı bildirilmiştir [27, 28]. EUROCAT'in amaçları:

- Avrupa'daki konjenital anomaliler hakkında temel epidemiyolojik bilgileri sağlamak

- Hastalıkların frekanslarındaki zamansal veya coğrafi farklılıkları izlemek, etiyolojik etkenleri ve savunmasız nüfus gruplarını tanımlamak,

- Yeni teratojenik maruziyetler hakkında erken uyarı yapılmasını kolaylaştırmak,

- Birincil korumanın etkinliğini ve prenatal taramalardaki gelişmelerin etkisini değerlendirmek,

- Nüfus, sağlık uzmanları ve yöneticiler için kümelenmeler, maruziyetler veya kaygı verici risk faktörleri hakkında bilgi ve kaynak merkezi olarak hareket etmek,

- Konjenital anomalilerin nedenleri ve önlenmesinin yanı sıra etkilenen çocukların tedavisi ve bakımı ile ilgili araştırma için bir işbirliği ağı ve altyapısı sağlamak,

- Karşılaştırılabilir, standart veri toplayan Avrupa çapında kayıtlar oluşturmak için katalizör görevi görmek olarak belirtilmiştir [8, 26, 27, 29].

\section{Gebelik Risk Sinıflandırmaları ve Özellikleri}

Teratojenite riskinin olduğundan düşük olarak değerlendirilmesi malformasyon riskini yükseltirken, olduğundan yüksek olarak değerlendirilmesi de annenin ilacı kullanma nedeni olan hastalığının tedavisinin yetersiz kalmasına ya da gebeliğin sonlandırılmasına neden olabileceğinden gebeliğin devamı konusunda karar verirken çok dikkatli olunmalıdır. 
Gebelikte ilaç veya herhangi bir etkene maruziyetten bağımsız olarak \%3-5 oranında temel bir konjenital anomali riski bulunduğundan, teratojenik etki riski değerlendirilirken bu oran göz önünde bulundurulmalıdır [30].

Sistemik dolaşıma geçerek fetüse zarar verme riski olan ilaçlar, teratojenik etki oluşturma riskinin boyutlarına göre farklı sinıflandırma sistemleri kullanılarak çeşitli alt gruplara ayrılmıştır. Bu risk gruplarına "gebelik risk sınıflandırmaları" denilmektedir. $\mathrm{Bu}$ sınıflandırmaların amacı risk standardizasyonunu sağlamaktır. İlk olarak 1978'de İsveç Onaylanmış İlaçlar Kataloğu (Farmaceutiska Specialiteter i Sverige $=$ FASS) risk sınıflandırması kullanılmıştır. $\mathrm{Bu}$ sistemde ilaçlar güvenliden riskliye doğru A, B, C, D olarak 4 gruba ayrılmış, B grubu da B1, B2, B3 olarak üç alt gruba bölünmüştür [31]. Ardından 1979'da ABD Besin ve İlaç Dairesi (Food and Drug Administration $=$ FDA)'nin ilaçların gebelikteki etkilerine dair gerçekleştirilmiş olan deneysel hayvan çalışmaları ve insanlardan sağlanan verilerin sunulma biçimine bir standardizasyon getirme çabası olarak "Gebelik risk kategorileri" oluşturulmuştur. Üreticilerin sistemik olarak emilime uğramayan ya da fetüs üzerine olumsuz etkileri olmadığı kesinlikle bilinen ilaçlar dışındaki ilaçlar için prospektüste FDA gebelik risk kategorileri bulundurmaları zorunlu tutulmuştur. Tablo I'de FDA risk kategorileri yer almaktadır [32-34].

FDA, gebelik risk kategorilerinin geliştirilmesi ve kullanıma sunulmasından 29 yıl sonra, mevcut risk kategorizasyonunun gebelikteki ilaç kullanımına dair riskleri tanımlamakta ve iletmekte yeterli olmadığına karar vermiş ve 29 Mayıs 2008'de Amerikan Resmi Gazetesi'nde yayımlanan bir yönetmelikle, ilaçların gebelik ve emzirme dönemindeki risklerine dair yeni bir anlatım yöntemine geçileceği, bu anlatımın "öyküleştirilmiş" şekilde olacağı, metnin risk özeti, klinik olarak göz önüne alınması gereken durumlar ve veriler gibi alanlara ayrılacağı duyurulmuştur. 30 Haziran 2015 'te uygulamaya giren yeni anlatım modelinde, hekimin klinik pratikte gebeye ilaç kullanımı ya da temasına dair daha iyi yol göstereceği düşünülmüştür, ancak klinik yorum gerekmektedir [34, 35]. Tüm reçeteli ilaçlarda gebelik harf sinıflandırmasının Haziran 2020 tarihine kadar kaldırılması karara bağlanmıştır [36]. Tablo II'de bu yeni anlatım şekli görülmektedir [8, 36, 37]

Talidomid faciasının ardından 1963 yılında, Avustralya İlaç Değerlendirme Kurulu (ADEC), federal hükümete bağımsız ve bilimsel tavsiyelerde bulunmak üzere sınıflandırma çalışmalarına başlamıştır. Kurul, ilaçların kalitesi, güvenliği ve etkililiğini değerlendirerek küresel boyutta önde gelen sinıflandırma sistemlerinden birinin oluşmasını sağlamıştır. Sınıflama sistemi 1989 'da başlatılmış, daha sonra Kurul isim değiştirerek, 2010'da ve 2017'de güncellenmiştir; halen "İlaçlar Hakkında Danışma Kurulu" adını taşımaktadır [38]. Harflendirmeler güvenliden teratojene doğru A, B1, B2, B3, C, D, X şeklindedir.

Tablo III'te Avustralya sağlık otoritesi tarafindan geliştirilmiş olan sınıflandırma sistemi bulunmaktadır [38].

Tablo 1. 2015 Öncesi FDA Risk Kategorileri [32-34].

\begin{tabular}{|c|c|}
\hline Sinıflar & Açıklaması \\
\hline A & $\begin{array}{l}\text { Gebelerden elde edilen yeterli, iyi-kontrollü çalışma verileri gebeliğin hiçbir periyodunda fetal anomali açısından } \\
\text { herhangi bir risk artışı göstermemiştir: Gebe (-) }\end{array}$ \\
\hline B & $\begin{array}{l}\text { Deney hayvanı çalışmaları fetüse zarar ile ilgili bir kanıt ortaya koymamıştır, ancak gebelerden elde edilen yeterli, iyi- } \\
\text { kontrollü çalışma verileri bulunmamaktadır: Gebe (?) Hayvan (-) } \\
\text { Deney hayvanı çalışmaları advers etki göstermiştir, fakat gebelerden elde edilen yeterli, iyi-kontrollü çalışma veriler } \\
\text { hiçbir periyotta fetüste bir risk olduğunu göstermemiştir: Gebe }(-)+\text { Hayvan }(+)\end{array}$ \\
\hline $\mathrm{C}$ & $\begin{array}{l}\text { Deney hayvanı çalışmaları advers etki göstermiştir ve gebelerden elde edilen yeterli, iyi-kontrollü çalışma verileri } \\
\text { bulunmamaktadır: Gebe (?)+ Hayvan (+) } \\
\text { Hayvan çalışmaları yapılmamıştır ve gebelerden elde edilen yeterli, iyi-kontrollü çalışma verileri bulunmamaktadır: } \\
\text { Gebe (?)+ Hayvan (?) }\end{array}$ \\
\hline $\mathrm{D}$ & $\begin{array}{l}\text { Gebelerden elde edilen yeterli, iyi-kontrollü veya gözlemsel çalışma verileri fetüste bir risk olduğunu göstermiştir: Gebe } \\
(+) \\
\text { Ancak, tedavinin yararı olası riske üstün olabilir. Örneğin, güvenli ilaçların kullanılamadığı ya da etkisiz kaldığı yaşamı } \\
\text { tehdit eden bir durumda ya da ciddi hastalıklarda, gerektiğinde ilaç kullanılabilir }\end{array}$ \\
\hline $\mathrm{X}$ & $\begin{array}{l}\text { Gebelerde ve deney hayvanlarında yapılan yeterli, iyi-kontrollü veya gözlemsel çalışmalar fetal anomaliler ya da riskler } \\
\text { hakkında pozitif kanıtlar göstermiştir: Gebe }(+)+\text { Hayvan }(+) \\
\text { Ürünün kullanımı hem gebelerde hem de gebe kalabilecek kadınlarda kontrendikedir }\end{array}$ \\
\hline
\end{tabular}


Bu sistemlerin tümü de ilk yıllarda kolay ve hızlı bir konsültasyon sağlamada yararlı olmuşsa da, bireysel danışmanlıklarda yetersiz kalmıştır. Bilgilerin eksik ve/veya muğlak olması kesin teratojenik risk ve gelişimsel toksisiteyi hesaplamayı zorlaştırdığı gerekçesiyle 2000'lerin başlarında bu üç sistem de güvenilirlik ve yararlılık bakımından eleştirilmiştir [10]. Örneğin, bir çalışmada her üç sistemin sınıflandırmaları karşılaştırılmış ve sadece \%26'sında ortaklık belirlenmiştir [31]

Yukardaki sistemlerin dışında olup Teratojen Bilgi Sistemi (TERIS) adıyla bilinen gebelik risk sinıflandırması, çeşitli ülkelerden çok sayıda klinik toksikoloji uzmanı bilim insanının katılımı ile oluşan, 3295'den fazla teratojenik etkeni içeren ve sürekli yenilenen bir bilgi bankası olup "Shepard's Catalog of Teratogenic Agents" olarak da adlandırılmaktadır [22].

Retrospektif araştırmalarda, aynı ilacı kullanan gebelerde \%3'ün üzerinde bir anomali oranı saptanmışsa da, bu ilaç hemen daima D ya da X kategorisinde sayıldığından, hekimlerin "doz-süre-dönem" ölçütlerini çok iyi değerlendirmeleri gerekmektedir [15].

\section{Teratojenite Danışma Servisleri}

\subsection{Teratojenite Danışma Servislerinin Tarihçesi}

ABD'de her yıl 150.000 bebek (tüm doğumların \%13'ü) fiziksel veya zihinsel doğum kusuru ile doğmaktadır. Çoğunun nedenleri bilinmemekle birlikte, radyasyon, alkol ve bazı ilaçlar gibi maruziyetlerin doğum kusurlarını artırdığı gösterilmiştir. Bu nedenle, ABD Sağlık ve İnsan Hizmetleri Bakanlığı (U.S. Department of Health and Human Services), Sağlık Dairesi Başkanlığı (Office of the Surgeon General) ve Tip Enstitüsü (Institute of Medicine), doğum kusurlarının önlenmesini ülkenin sağlığı için altı öncelikten biri olarak belirlemiştir [39].

20. yy'dan önce, doğuştan malformasyonların genetik faktörlerin sonucu olduğuna inanılıyordu. Yirminci yüzyılın başlarında, hayvan araştırmacıları çevresel risk artışlarından kaynaklanan doğuştan anomalileri gözlemlemeye başladılar. Örneğin, 1922'de Bragg, radyasyona maruz kalmış farelerin yavrularında göz kusurları tanımladı; 11 yıl sonra Hale, ekinlerdeki A vitamininin eksik olması nedeniyle domuzlarda sik-

Tablo 2. Gebelikte İlaç Maruziyetine Dair FDA Tarafından Kabul Edilen Yeni Anlatım Modeli [8, 36].

\begin{tabular}{|c|c|}
\hline Başlıklar & Kapsam \\
\hline Gebelik kayıt sistemi ifadesi & $\begin{array}{l}\text { İlaca gebelik döneminde maruz kalma durumuna dair mevcut bir kayıt sistemi ya } \\
\text { da çalışma var ise kaydolmak isteyen gebeler için iletişim bilgileri }\end{array}$ \\
\hline Gebeliğe dair bazal risk ifadesi & $\begin{array}{l}\text { "Tüm gebeliklerde ilaç kullanımından bağımsız olarak belirli bir oranda doğum } \\
\text { kusuru, kayıp ya da diğer istenmeyen sonuç riskleri bulunmaktadır. Aşağıdaki } \\
\text { fetal risk özeti A ilacının gelişimsel anomalileri bu temel riskin ne kadar üzerine } \\
\text { çıkarma olasılığı olduğunu tanımlamaktadır." gibi bir ifade yer alacaktır. }\end{array}$ \\
\hline Fetal risk özeti & $\begin{array}{l}\text { Bu bölümde mevcut veriler üzerinden ilacın insanlarda gelişimsel anomalileri ne } \\
\text { ölçüde artırabileceği açıklanacaktır. İlaçların hangi yol (sistemik, topikal vb.) ile } \\
\text { kullanıldıkları da göz önüne alınacaktır. }\end{array}$ \\
\hline Klinik değerlendirmeler & $\begin{array}{l}\text { Bu bölümde aşağıdaki konularda bilgiler olacaktır. } \\
\text { - İstemeden maruz kalma (gebelik henüz öğrenilmeden önceki maruz kalımlar) } \\
\text { - Gebelere yönelik reçeteleme kararları } \\
\text { - İlacın kullanılacağı hastalığın gebe ve fetüs üzerindeki riskleri } \\
\text { - Gebelikte doz ayarlanmasına dair bilgiler } \\
\text { - Gebelikte sıklığı artan ya da gebeliğe özgü anneye ait istenmeyen etkiler } \\
\text { - İlaca maruz kalma dozunun, zamanının ve süresinin etkileri } \\
\text { - Olası yenidoğan komplikasyonları ve müdahale yöntemleri } \\
\text { - İlacın doğum esnasındaki etkileri }\end{array}$ \\
\hline Veriler & $\begin{array}{l}\text { İnsan ve hayvan verileri; insan verileri önce olacak şekilde gösterilecektir. } \\
\text { - Çalışmanın tipi, maruz kalma durumuna dair bilgiler (doz, süre, zaman) ve fetüste } \\
\text { tanımlanmış herhangi bir gelişimsel anomali ya da diğer istenmeyen etkiler } \\
\text {-Pozitif ve negatif deneyimleri kapsayan insan verileri, çalışmaya alınan olgu sayısı } \\
\text { ve çalışmanın süresi } \\
\text { - Çalışılan türleri ve çalışılan dozu insan dozu eşdeğerinde tanımlayan hayvan } \\
\text { verileri }\end{array}$ \\
\hline
\end{tabular}


Tablo 3. Avustralya Gebelikte İlaç Kullanımı Sınıflandırması [38]

\begin{tabular}{|c|c|}
\hline Sinıf & Açıklama \\
\hline A & $\begin{array}{l}\text { Çok sayıda gebe ve doğurganlık çağındaki kadın tarafından kullanılmış, ancak fetüste malformasyon veya diğer } \\
\text { doğrudan ya da dolaylı zararlı etkilerin sıklığında artma gözlenmemiş olan ilaçlar. }\end{array}$ \\
\hline B1 & $\begin{array}{l}\text { Sadece sınırlı sayıdaki gebe ve doğurganlık çağındaki kadın tarafından kullanılmış, ancak insan fetüsünde } \\
\text { malformasyon veya diğer doğrudan ya da dolaylı zararlı etkilerin sıklığında artma gözlenmemiş olan ilaçlar. } \\
\text { Hayvanlardaki çalışmalarda fetal hasarın arttığına dair kanıt gösterilmemiştir. }\end{array}$ \\
\hline $\mathrm{B} 2$ & $\begin{array}{l}\text { Sadece sınırlı sayıdaki gebe ve doğurganlık çağındaki kadın tarafından kullanılmış, ancak insan fetüsünde } \\
\text { malformasyon veya diğer doğrudan ya da dolaylı zararlı etkilerin sıklığında artma gözlenmemiş olan ilaçlar. } \\
\text { Hayvan çalışmaları yetersiz veya eksik olabilir, fakat mevcut veriler fetal hasarın arttığına dair kanıt göstermemiştir. }\end{array}$ \\
\hline B3 & $\begin{array}{l}\text { Sadece sınırlı sayıdaki gebe ve doğurganlık çağındaki kadın tarafından kullanılmış, ancak insan fetüsünde } \\
\text { malformasyon veya diğer doğrudan ya da dolaylı zararlı etkilerin sıklığında artma gözlenmemiş olan ilaçlar. } \\
\text { Hayvan çalışmalarında fetal hasarın arttığına dair kanıtlar gösterilmiştir, bu durumun insanlardaki önemi kesin } \\
\text { değildir. }\end{array}$ \\
\hline $\mathrm{C}$ & $\begin{array}{l}\text { Farmakolojik etkileri nedeniyle insan fetüsünde ya da yenidoğanda malformasyonlara yol açmaksızın zararlı etkilere } \\
\text { neden olan veya olabileceğinden kuşkulanılan ilaçlar. Bu etkiler geriye dönüşlüdür. Ayrıntılar için ek kaynaklara } \\
\text { başvurulmalıdır. }\end{array}$ \\
\hline $\mathrm{D}$ & $\begin{array}{l}\text { İnsanda fetal malformasyonların veya geriye dönüşsüz hasarın sıklığında artmaya neden olan veya olduğundan } \\
\text { kuşkulanılan ya da neden olması beklenilen ilaçlar. Bu ilaçların advers farmakolojik etkileri de olabilir. Ayrıntılar } \\
\text { için ek kaynaklara başvurulmalıdır. }\end{array}$ \\
\hline $\mathrm{X}$ & $\begin{array}{l}\text { Fetüste kalıcı hasara neden olma riski yüksek olduğu için gebelikte veya gebelik olasılığında kullanılmaması } \\
\text { gereken ilaçlar }\end{array}$ \\
\hline
\end{tabular}

lopi (iki göz küresinin birleşmesiyle oluşan boşlukta tek göz bulunması durumu) geliştiğini bildirdi. İkinci Dünya Savaşı yıllarında, sıçanlarda annenin beslenme eksikliklerinin yavrulardaki etkilerine ilişkin kapsamlı araştırmalar başlatıldı. Sonuç olarak çevresel maddelere maruz kalmanın doğuştan malformasyonlara neden olabileceği hipotezi doğrulandı [5].

1957 yılında önce Almanya'da piyasaya sürülen Talidomid, aralarında İngiltere, Kanada, Japonya gibi ülkelerin de bulunduğu 50'den fazla ülkede, en az 37 ticari ad ile gebeler tarafindan başta sedasyon ve bulantı/kusma olmak üzere çeşitli endikasyonlar için yaygın şekilde kullanılmıştır. O dönemin ilaçla ilgili ihtiyaçları karşılamayan yasal düzenlemeler ortamında Talidomidin farelerde sedatif-hipnotik etkilerini gösteren ve verilerinin sorgulanabilir nitelikte olduğu tek çalışma bulunmaktaydı. Diğer deney hayvanlarında kapsamlı toksikoloji çalışmaları olmaksızın, sadece bu çalışmaya dayanarak talidomidin insanlarda kullanılmaya başlandığı bilinmektedir. Önce periferik nöropati, konstipasyon, halsizlik, baş ve kas ağrıları gibi yan etkiler dikkati çekmişse de, asıl trajedi doğumlar gerçekleşmeye başlayınca ortaya çıkmıştır. Gebelikleri sırasında tek talidomid dozu alanlarda bile teratojenik etkinin görüldügüü bilinmektedir, öyle ki başlangıçtaki konjenital malformasyon riski \%1.5-2 iken talidomid ile bu oran $\% 20$ ' ye ulaşmıştır. Tahminen 10.000 civarında bebeğin başta ekstremite defektleri (fokomeli [geliş- memiş kol ve bacaklar]) olmak üzere yüz, omurga, böbrekler, bağırsaklar ve kalbi kapsayan çeşitli konjenital malformasyonlarla ("Talidomid embriyopatisi") doğmasına neden olmuş, çocukların yaşları ilerledikçe çeşitli kemik rahatsızlıkları ve ciddi kalp hastalıklarına yatkın oldukları da ortaya çıkmıştır. İçlerinde $A B D$ ve Türkiye'nin de bulunduğu, ilaca ruhsat vermemiş olan bazı ülkelerde bu tabloyla karşılaşılmamış olması büyük bir avantaj sayılmaktadır $(10,22)$. İlaç halen lepra tedavisinde kullanılmakta, ayrıca immünmodülatör olarak sistemik lupus eritematozus, greft versus host hastalığ1, multipl myeloma, myelodisplazi ve bazı neoplazmların tedavisinde de yer bulmaktadır [40]. Ancak gebeler için en yüksek oranda uyarılarda bulunulmakta ve ciddi kayitlar tutulmaktadir.

$\mathrm{Bu}$ facia ile birlikte ilaçların teratojenik riskler içerebileceği düşüncesi hekimlerde ve gebelerde ciddi bir kaygı oluşturmuş ve ilaçlar hakkında bir danışma hizmeti alma ihtiyacını doğurmuştur [2]. Bu gereksinim üzerine dünyada ilk teratojenite bilgi servisi (TBS) ABD'nin San Diego şehrinde 1979 yılında kurulmuştur. ABD ve Kanada'da, Reprotox ${ }^{\circ}$ gibi üreme üzerine etkileri olan ajanlar hakkında bilgilerin derlenmesini amaçlayan veritabanlarının geliştirilmesi de dahil olmak üzere teratoloji bilgi hizmetlerinin sayısında bir artış olmuş ve bu hizmetler dünya çapında çoğalmıştır [5]. 
Şu anda iki TBS ağı bulunmaktadır: ABD, Kanada ve bazı Asya ülkelerinde bulunan hizmetleri temsil eden Teratoloji Bilgi Uzmanları Örgütü "OTIS" ve Avrupa Teratoloji Bilgi Hizmetleri Ağı adıyla Avrupa, Asya, Güney Amerika ve Avustralya'da TBS'yi temsil eden "ENTIS". OTIS ve ENTIS' in kuruluşunun temel amacı TBS'leri ortak bir ağ altında toplamaktır [41].

\subsection{Teratoloji Bilgi Uzmanları Örgütü (OTIS)'nün Geliştirilmesi}

OTIS, 1990 yılında Utah Park City'deki Uluslararası Üçüncü Teratoloji Bilgi Hizmetleri Konferansı sırasında kurulmuştur. Bu toplantıda klinik teratoloji ile ilgili bilgi ve eğitim sağlayan uluslararası bir organizasyon olarak tanımlanan OTIS, kuruluşundan bu yana, teratoloji bilgi programları arasında iletişimi kolaylaştırma, ortak veri tabanı bilgilerine erişim sağlama, muhtemel hamilelik sonuç verilerini bilimsel bir şekilde kullanma şeklinde yararlar sağlamıştır. Program kadrosu, teratoloji bilgi hizmetleri için kılavuzlar geliştirmek üzere Genetik Hizmetler Bölgesel Ağları Konseyi gibi diğer kuruluşlarla da işbirliği yapmaktadır. OTIS, ENTIS ile de bağlantıdadır [5].

$A B D$ ve Kanada'da 45'ten fazla üye kuruluşun ortak ağı olan OTIS, bilgilendirme ve veri toplama çalışmaları dışında ilaçlar ve teratojenik etkileri üzerine de çalışmalar yapmaktadır. Örneğin suçiçeği enfeksiyonu, sumatriptan, sisaprid, klaritromisin, florokinolonlar ve psikotropik ilaçların yanı sıra anjiyotensin dönüştürücü enzim inhibitörlerine maternal maruziyet ile ilgili çeşitli çalışmalar tamamlanmıştır. Ayrıca gebelikte astım ilaçları ve romatoid artrit için kullanılan leflunomide maternal maruziyet üzerine de çalışmalar yapılmış, başvurular dönem dönem istatistiksel olarak değerlendirilerek daha sonraki çalışmalar için 1şık tutulmaya çalışılmıştır [42]. Bunlara ek olarak, hekimlerin hastalarına dağıtmaları için fluoksetin, toksoplazmozis, hipertermi ve beşinci hastalık gibi pek çok konuda 'bilgi formları" hazırlanmıştır [5].

\subsection{Avrupa Teratoloji Bilgi Hizmetleri Ăg (ENTIS)'nın Geliştirilmesi}

1990 yılında, risk altındaki hamile kadınlara danışmanlık yapmak, hamilelik sonuçlarını değerlendirmek ve izlemek üzere 13 Avrupa ülkesinin ilgili kurumlarının üyeleri Milano'da bir araya gelmiş ve ENTIS'i (https://www.entis-org.eu) kurmuşlar- dır. Ajans Hollanda'da resmileştirilmiş olup, halen Bilthoven'deki Ulusal Halk Sağlığı ve Çevre Koruma Enstitüsü'nde hizmetlerini sürdürmektedir [21]. 2011 itibariyle üniversite hastanelerine veya diğer sağlık kuruluşlarına bağlı 30 'dan fazla TBS, ENTIS ile işbirliği yapmakta olup, kuruluşun özelliklerine göre yılda birkaç yüz - on beş bin arasında bilgi talebinde bulunmaktadır [12].

ENTIS, doğum kusurlarını önlemek için etkenleri belirleyip saptamak, Avrupa'daki farklı TBS deneyimlerinin değişimini teşvik edip kolaylaştırmak, gebelikte risk değerlendirmesinde danışmanlık becerilerini geliştirmek, teratoloji bilgilendirmesi konusunda eğitim vermek, prosedürleri ve terminolojiyi uyumlu hale getirmek, bilimsel işbirliğini geliştirmek ve organizasyon prosedürlerini geliştirmek için yıllık toplantılar düzenlemek gibi amaçlar belirlemiştir [21].

Geniş kapsamlı prospektif çalışmaların veya sistematik değerlendirmelerin yetersizliği nedeniyle, ENTIS'e üye TBS'ler yıllık toplantılarda belirlenen özel çalışmalara da katılabilmektedir; kinolonlar, antidepresanlar ve A vitamini ile ilgili olanlar bunlara örnek olarak verilebilir [21].

Gebelik ve emzirme döneminde ilaçların riskleri hakkında düzenli olarak güncellenen bilgilerin yayılmasını teşvik etmek amacıyla, bazı servisler bilgilendirici web siteleri (Paris TBS [http://www. lecrat.fr] ve Berlin TBS [https://www.embryotox. de/]) kurmuştur. Örneğin Berlin TBS'nin web sitesi en sık sorgulanan 400 ilacın gebelik üzerine etkileri konusunda bilgiler içermekte, ayrıca sitede bulunan çevrimiçi bir anket sistemi ile danışanların bireysel risk değerlendirmesi için Berlin TBS ile bağlantıya geçmelerine olanak sağlanmaktadır [12].

$\mathrm{Bu}$ genel ağlar dışında ülkelerin kendi içinde kurdukları danışma servislerinin finansal desteklenmesi farklı şekillerde olmaktadır. Örneğin Hollanda Bilgi Servisi, Ulusal Halk Sağlığı ve Çevre Koruma Enstitüsü Teratoloji Bölümü bünyesinde faaliyet göstermekte ve Hollanda hükümetinin Sağlık Müfettişliği tarafindan desteklenmektedir [21].

\subsection{TBS Neler Yapar? Kimlere Hizmet Sağlar?}

Türkiye'de yapılan bir çalışmada, gebelerin yaklaşık \%6'sının D ve \% 3'ünün de X sınıfı ilaçlara maruz kaldığı bildirilmektedir [4].

Tedavi veya tanı amaciyla gebe kadınlarda zorunlu olarak kullanılacak ilaçların seçiminde çeşitli sınıf- 
landırmalardan ve ayrica TBS'den yararlanılmaktadır. Bu hizmetler, hamile kadınlara, hamileliği planlayan kadınlara, emziren kadınlara, bu kadınların ailelerine ve hekimlere, üreme güvenliği veya doğum öncesi çeşitli ajanlara maruz kalma riskleri konusunda danışmanlık vermeye odaklanmaktadır. İdeal olarak, gebelik planlama aşamasındayken danışmanlık yapılır, ancak tüm gebeliklerin yarısının plansız olduğu bildirildiğinden danışmanlıkların çoğu gebelik sürecinde yapılmaktadır [43].

Hekimler ve hastalar TBS'lerden yararlanmaktadır. $\mathrm{Bu}$ kuruluşlarda kanıta dayalı çalışmalar yürütülüp raporlanmaktadır. TBS, başvuranlardan bilgi toplamak ve ilaçların güvenliliğini denetlemek için kurulmuş olduğundan, mükemmel bir araştırma ortamı olup ileriye dönük çok merkezli çalışmaların yapılması açısından, gebelikte ilaç kullanımına ilişkin en değerli veri kaynaklarından biridir [1, 43].

TBS'nin amacı, belirli bir ajanın normal embriyonik veya fetal gelişime müdahale potansiyeli ile ilgili soruları ele almak için teratoloji, dismorfoloji, toksikoloji, farmakoloji, epidemiyoloji, klinik genetik, obstetrik tıp, bulaşıcı hastalık ve mesleki sağlığ temsil eden multidisipliner uzmanlıkların sağladığı bilgileri derleyerek sunmaktır [41].

TBS uzmanları veya danışmanları, literatürdeki ilgili bilgileri sentezler ve hamile bir kadın özelinde doz, gebelik zamanlaması ve uygulama yolu dikkate alınarak maruz kalınan ajan için geçerli bireysel risk değerlendirmesi geliştirmek amacıyla multidisipliner kaynaklara ve uzmanlara danışır. Ek olarak, riskin ailelerde panik yaratmayacak veya konuyu önemsizleştirmeyecek bir şekilde, gebenin duyarlılığına anlayış gösteren bir yaklaşımla iletilmesinde de etkin rol oynamalıdır. ABD'de TBS'lerin yapısı çeşitlilik göstermekte ise de genellikle akademik bir merkezde veya hastanede bulunmakta ve hizmet, genetik danışmanlık, hemşirelik, eczacılık ve sağlık eğitimini kapsayan çeşitli geçmişlerden gelen eğitilmiş danışmanlar tarafından sunulmaktadır. ABD ve Kanada'daki TBS'ler, öncelikli olarak ücretsiz telefon danışmanlığı sağlamakta, ancak bazıları, yüz yüze ziyaretler, e-posta veya sohbet yoluyla da ek erişime olanak vermektedir. Hizmetler ABD'deki devlet, yardım kuruluşları veya diğer yerel kaynaklar ve Kanada'daki tıbbi bakım sistemi tarafından finanse edilmektedir [41].

TBS'ler kronik hastalık öyküsü olan gebelerin tedavisinin düzenlenmesi, ya da ilk hastalık tanısını gebelik döneminde almış olan anne adayları için tedavi planlanması konusunda da hekimlere kanıta dayalı bilgi sunarlar. Metotreksat, leflunomid gibi bazı ilaçların gebelik oluşmadan önce kesilmesi, kesildikten sonra da metabolitlerin organizmadan uzaklaşması için bir süre beklenmesi gerektiğinden, doğurganlık çağındaki tüm kadınlara bu tür ilaçları reçete etmeden önce TBS'lere danışarak konuya ilişkin en güncel bilgilerin alınması da önemlidir [15]. TBS'lere daha az sıklıkla da olsa gebelik planlayan çiftler paternal maruziyetle ilgili danışmanlık için de başvurmaktadır [2].

Teratojenite bilgi servislerinin işlevleri büyüklük, hizmet verilen popülasyon, hizmet sunumu ve araştırma hedeflerine göre farklılaşmaktadır. Bazı servisler bir veya iki kişiden oluşan bir personele sahipken bazılarında beş veya altı kişi bulunabilir. Bazı programlar yalnızca hekimlere bilgi sağlarken, diğerleri halka da açıktır. Telefonla bilgi veren bazı programların yanı sıra; şahsen ziyarete ihtiyaç duyanlar da bulunmaktadır. Bazıları, arayan kişinin hekimine mektuplar aracılığıyla bilgi verirken, bir kısmı da, veri tabanlarından yararlanmaktadır. Bazı bilgi hizmetleri programları araştırmalar yürütmekte ise de bazılarında bu işlev bulunmamaktadır [5].

Genel olarak, TBS'lerin temel hedefleri olan önlenebilir doğumsal anomalilerin sayısını azaltmak ve korunmak için risk faktörlerini tanımlamak ve gebeye maruziyetin getireceği riskler konusunda en doğru bilgiyi sağlayarak özellikle istenen gebeliklerin gereksiz yere sonlandırılmasını önlemek doğrultusunda, şu amaçlarla hizmetler yürütülmektedir:

- Gebelik öncesi dönemde sigara, alkol, uyuşturucu ve diğer toksik maddelerden uzaklaştırılarak sağlık iyileştirilmelidir.

- Özellikle gebelik öncesinde olmak üzere kronik hastalıkları olan kadınlara tedavi seçenekleri ve ilaçların etkileri konusunda danışmanlık verilmelidir.

- Tüm akut ve kronik hastalıklar hamilelik sırasında izlenmelidir.

- Gereksiz ilaçların kullanılmasını önlemek için kadınlara danışmanlık verilmelidir.

- Yüksek riskli ilaçlar yerine daha düşük risk taşıyan eşit derecede etkili tedaviler varsa, teratojenik etkisi düşük olanların kullanımına öncelik verilmelidir.

- Maternal ve fetal sağlığa zarar vermeden maternal hastalığ sayıda ilaç ve en düşük doz kullanılmalıdır. 
- Gebeliğin yanı sıra emzirme döneminde de maruz kalınan maddeler konusunda danışmanlık hizmeti verilmelidir.

- Risk faktörleri tanımlanmalıdır.

- Deneyim aktarımı teşvik edilerek ve danışmanlık eğitim kursları verilerek sağlıkçılara ve topluma bilgilendirme yapılmalıdır [2,6].

\subsection{TBS İşleyişi}

Danışmanlık hizmeti için, TBS'ye ilaç danışmanlığ1 amaciyla başvuran gebenin 20-40 dakikalık bir görüşme sonucunda demografik bilgilerinin de yer aldığ 1 bir kayıt formu doldurulur ve ayrıntılı risk değerlendirmesine başlanır [2, 15]. Sigara, alkol, yasadışı ve kötüye kullanılabilen madde ya da bitkisel ilaç kullanım alışkanlıkları ve radyasyon maruziyeti sorgulanır. Kronik hastalığı olup olmadığı ve folik asit alma durumu da kaydedilir. Gebenin maruz kaldığı ilaç(lar) mümkün olan en ayrıntılı şekilde sorgulanır. İlacın endikasyonu, tedavinin ne zaman başladığ 1 , gebenin ilacı halen kullanıp kullanmadığ ${ }_{1}$, ne şekilde ve hangi dozlarda kullandığı kaydedilir ve bu bilgilerle risk değerlendirmesine geçilir [44].

Daha sonra maruz kalınan etken(ler)le ilgili literatür araştırması yapılır. Risk değerlendirmesi için embriyoloji, teratoloji ve farmakoloji referans kitapları; ulusal ve uluslararası bilimsel literatürden birincil kaynaklar; literatür tarama sistemleri (TERIS, Reprotox, Toxline, Medline, Biosis) ve yerel merkezlerde toplanan verilerdeki benzer maruziyetlerden elde edilen hamilelik sonuçlarından yararlanılmaktadır [45]. Maruz kalınan ilaçlar varsa çeşitli gebelik risk kategorilerine (FDA, FASS, Avustralya Gebelikte İlaç Kullanımı Sınıflandırması vs ) göre de değerlendirilir ve sonunda teratojenite ile ilgili bir rapor hazırlanarak hastanın hekimine iletilir. Yapılan birçok çalışma uygun risk iletişiminin teratojenite algısı üzerine ciddi etkilerinin olduğunu gösterdiğinden, rapor hazırlama aşamasının sonucunda gebe ile de iletişimde bulunulmalıdır $[2,8]$.

Gebeye verilen danışmanlıkla, riskin mevcut veriler 1şı̆̆ında doğru bir şekilde anlaşılabilmesi amaçlanmaktadır. Gebenin anlatılanları anladığ lanmalı, anlatılanlar yazılı olarak da verilmelidir. Gebeliklerde kararın anne ve babaya ait olduğu ve TBS'nin yönlendirmesi varsa eğer, bunun bir öneri olduğu vurgulanmalıdır [46].

TBS başvurularında, hamile kalmak isteyen bir ka- dına kronik hastalığı nedeniyle (epilepsi, diyabet vb.) reçete edilen ilacın güvenli olup olmadığı, güvenli değilse hangi ilacın daha güvenli olabileceği; hamile olduğunun bilinmediği dönemde bir ilacı ya da bir maddeyi kullanmış olmanın riski ve bu durumda hamileliğin sonlandırılmasının gerekli olup olmadığ 1 şeklindeki sorular örnek verilebilir. Ayrıca, retrospektif olarak da doğum kusuru ile doğan bir bebek olgusunda hamilelikten önce veya hamilelik sırasında maruz kalınan bir ajanın söz konusu olup olmadığı araştırılmalıdır. Retrospektif sorular çocukluk hatta ergenlik döneminde ortaya çıkan zihinsel, davranışsal veya fonksiyonel bozukluklarla da ilgili olabilir. Bu durumlar, birçok etkenle (babanın ilaca maruz kalması, kasitlı zehirlenmeler, ev temizlik ürünleri, pestisitler vb. kimyasal maddelere istemli veya istemsiz maruz kalma ya da ilaçların anne sütüne geçmesi) ilgili olabilir [46].

Bir çeşit derleme olan teratojenite raporu gebeden gebeye farklılık gösterse de ortalama 48 saatte hazırlanmaktadır [15].

\subsection{Danışmanlık Metodolojisi}

Tüm merkezler tarafindan veri toplama için standart prosedürler uygulanmaktadır. Her TBS biriminin kendine özgü çalışma prosedürü olmasına rağmen, son yıllarda ENTIS içinde bazı ortak yöntemler oluşturulmuş̧ur. Araştırma sırasında veriler toplanır. Verilerin teslimat tarihinden 3-12 ay sonra, kadınlardan ve / veya hekimlerinden TBS personeli ile posta veya telefon ile bağlantı kurarak gebeliğin sonucu (düşük, kürtaj veya doğum); bebek ile ilgili bilgiler (bebeğin doğum kilosu, baş çevresi ve boyu); perinatal komplikasyonlar ve varsa majör konjenital malformasyon hakkında bilgiler sağlanır [21].

\subsection{Paternal İlaç Maruziyeti}

Birçok çalışma annenin teratojen etkenlere maruziyetinin etkilerini kapsamlı bir şekilde incelemiş olsa da, babanın maruziyeti üzerindeki bilimsel deneyim daha sinırlıdır. Her gebeliğin \%5'inin konjenital anomali riski taşıdığı ve yenidoğanlarda gözlenen konjenital anomalilerin \%65-70'inin bilinmeyen bir etiyolojiye sahip olduğu düşünüldüğünde, bu bilinmeyen nedenlerin bir kısmının babanın ilaca / etkene maruziyetine bağlı olabileceği sonucuna varılabilir. Paternal maruziyet, eş gebe kalmadan önce veya gebe iken, fetüsün babasının maruz kaldığ 1 terapötik, mesleki, çevresel veya sigara, alkol vb. sosyal ajanlardır $[30,47]$. Ba- 
badan kaynaklanan advers etkilerin temel nedenleri direkt mutajenik etkiler, spermatognenez üzerine etkiler veya ilacın / maddenin semen aracılığıyla kadına taşınması şeklinde olmaktadır [48].

TBS'den paternal ilaç maruziyeti konusunda talep edilen bilgilerin, toplam çağrıların \% 1,2'sini yansıttığı kaydedilmiştir. TBS'leri arayanların bir kısmının babanın ilaca maruziyeti (\%76, kemoterapi dışındaki ilaçlar) ve kanser tedavisi (\%17, kemoterapi ve/veya radyoterapi) hakkında bilgi istediği bildirilmektedir. Diğer bir kesimin ise radyasyona (\% 4), suistimal edilen ilaç ve maddelere (\%2) ve mesleki kimyasallara (\%1) maruz kalmalarıyla ilgili danıştıkları gösterilmiştir. Paternal ilaçlar arasında nörolojik bileşikler, immünosüpresif ilaçlar ve antiviral ajanlar en sık danışılan maddeleri oluşturmaktadır [49].

Bu konuyla ilgili olarak ilk kez 1970'lerde boyacılık, kaynakçılık, itfaiyecilik vb. işlerde çalışan babanın mesleki toksik maddelere sürekli temasının risklerine dikkat çekilmiş ve 1990 'larda da bu maruziyetlerin spontan abortus, doğumsal anomaliler ve çocukluk çağı kanserlerine yol açabileceğine ilişkin çalışmalar yayımlanmışsa da konunun geniş epidemiyolojik araştırmalarla kanıtlanmasının zorunlu olduğu ortaya çıkmıştır [47] Halen insanlarda, babanın ilaca maruziyetinden sonra doğum kusurları geliştiğine dair kanıt yoktur, ancak olası riskleri en aza indirmek için, radyoterapiye ve kemoterapiye maruz kalan erkeklerin, tedavinin bitiminden sonra en az 3 ay boyunca çocuk sahibi olma planlamasını geciktirmeleri önerilmektedir. Teratojenik potansiyeli maternal maruziyet bakımından iyi değerlendirilmiş veya teratojen olduğundan kuşku duyulan ilaçlarla tedavi edilen erkek hastalara tedavi sırasında ve sonrasında doğum kontrolü uygulaması ile ilk üç aylık dönemde vajinal duvarlarla semen temasından kaçınmaları konusunda öneriler bulunmaktadır [49].

\section{8. Ülkemizdeki Durum}

Ülkemizde TBS yapılanması oldukça yenidir. Bu merkezlerin faaliyetlerinin önemli bir kısmını hekimlere ya da gebelere verilen teratojenite danışmanlığı oluşturmaktadır. Ülkemizde genellikle ilgili üniversitelerin Tıp Fakültesi Tibbi Farmakoloji Anabilim Dalları tarafindan üstlenilen TBS hizmeti Dokuz Eylül, Karadeniz Teknik, İzmir Kâtip Çelebi, Marmara, Pamukkale, Celal Bayar, Adnan Menderes, Çanakkale 18 Mart, İstanbul, Şifa, Muğla Sitkı Koçman, Fırat ve Tokat Üniversiteleri Tıp Fakültelerinin
Tıbbi Farmakoloji Anabilim Dallarında görevli hekimler tarafından verilmektedir [44]. Sadece 25 Mart 1992 - 13 Mart 2021 tarihleri arasında Hacettepe Üniversitesi Eczacılık Fakültesi bünyesinde hizmet vermiş olan Hacettepe İlaç ve Zehir Bilgi Birimi-Teratojenite Bilgi Hizmetleri'nde eczacılar görev yapmıştır.

Yukarıda sayılan mevcut kuruluşlar tarafından verilen hizmet yetersiz kalmaktadır. Ayrıca bu hizmetin verilmesi ile ilgili yasal düzenlemelerde de ciddi eksiklikler söz konusudur. Bu hizmetin ülke genelinde optimum düzeyde verilebilmesi organize bir yapılanma çerçevesinde yürütülmelidir; bu amaçla Sağlık Bakanlığı, Yüksek Öğretim Kurulu ve Sosyal Güvenlik Kurumu'nun işbirliği oluşturması ülkemizde teratojenite danışmanlık hizmetinin ilerlemesi için itici güç yaratacaktır [2].

Aşağıda, ülkemizde hizmet vermekte olan bazı merkezler hakkında kısa bilgiler verilmektedir:

\subsubsection{Dokuz Eylül Ilaç ve Zehir Danışma Merkezi}

Tıp Fakültesi Farmakoloji Anabilim Dalı Klinik Toksikoloji Bilim Dalı içinde hizmet vermektedir. 1993 yılında kurulan merkeze, Dokuz Eylül Üniversitesi Tıp Fakültesi Hastanesi aracılığıyla mesai günlerinde 08.30-17.30 saatleri arasında erişilebilmektedir. İlaç kullanımı ve zehirlenmelerle ilgili başvurular kapsamında gebelikte güvenli ilaç kullanımı konusunda da bilgilendirme sağlanmaktadır. (Teratojenite Bilgi Servisi Pazartesi-Çarşamba günleri 13:30-17:00 saatleri arasında poliklinik hizmeti vermektedir). Merkezin resmi web sitesinin adresi aşağıdadır : http:// web.deu.edu.tr/zdm/tr/index_dosyalar/page 0001 . html [50].

\subsubsection{Trabzon Karadeniz Teknik Üniversitesi Teratojenite Araştırma ve Uygulama Merkezi}

2015 yılında yayımlanan Resmi Gazete'de yer alan yönetmeliğe göre merkezin amaçları "gebelik ya da emzirme döneminde ilaç kullanımı hakkında başvuran gebe ya da sağlık çalışanlarına konu ile ilgili kanıta dayalı bilgi sağlamak, üniversitede teratojenite konusunda öğretim elemanı yetişmesini teşvik edip gerekli ortam ve imkânları hazırlamak, bilimsel toplantılar düzenlemek, eğitim ve yayım yapmak, ilgili diğer kuruluşlarla işbirliği yapmak, bilgi alışverişinde bulunmak ve ortak projeler üretmek, konuyla il- 
gili olarak ülkesel ve yerel ihtiyaçlara öncelik veren araştırma projeleri hazırlamak" olarak belirtilmiştir [51].

Merkezin resmi web sitesinin adresi: http://www.ktu. edu.tr/teratojeniteuam

\subsection{3.İzmir Kâtip Çelebi Üniversitesi}

$\mathrm{Bu}$ merkez ENTIS üyesi olarak hizmet vermekte olup İzmir Kâtip Çelebi Üniversitesi Atatürk Eğitim ve Araştırma Hastanesi Klinik Farmakoloji ve Toksikoloji Birimi bünyesindedir. Başlıca amaçları sağlık çalışanlarına ve topluma gebelik ve emzirme döneminde maruz kalınan etkenlerle ilgili olarak kanıta dayalı bilgi sunmak, danışmanlık hizmeti ve eğitim vermek böylelikle doğum kusurlarının önlenmesine katkıda bulunmak, gebeliklerin yanlış yüksek risk algısı nedeni ile gereksiz şekilde sonlandırılmasını önlemek, teratojenik kimyasallarla ilgili araştırma geliştirme faaliyetlerini koordine etmek ve bu alanda birbirinden bağımsız yapılan çalışmaları birleştirmek ve yürütmektir $[1,52]$.

Merkezin resmi web sitesinin adresi : https://terafar. ikcu.edu.tr

\subsubsection{Hacettepe Ilaç ve Zehir Bilgi Birimi- Teratojenite Danışma Hizmetleri (HIZBIB)}

İlaç ve Zehir Bilgi Hizmeti Projesi, Hacettepe Üniversitesi Eczacılık Fakültesi'nde 1980'lerde başlatılmış, 25 Mart 1992'de Hacettepe İlaç ve Zehir Bilgi Merkezi (HIZBİM) adıyla resmen kurulmuş, daha sonra adı Hacettepe İlaç ve Zehir Bilgi Birimi’ne (HİZBİB) dönüştürülmüştür. Söz konusu Birim güncel teknoloji ve veritabanlarını kullanmış, deneyimli çalışanlarıyla, birikim ve olanaklarını sağlık personelinin ve toplumun hizmetine sunmaya çalışmıştır [53].

Hizmetlerine 2015'te, Hacettepe Üniversitesi Kadın Hastalıkları ve Doğum Anabilim dalı ile birlikte başlatılan bir proje çerçevesinde, hastalarla yüz yüze diyalogla ayrıntılı teratojenite değerlendirilmesi işlevi de eklenmiştir. Bu amaçla HİZBİB tarafindan geliştirilen formlar, Hacettepe Üniversitesi Kadın Hastalıkları ve Doğum Anabilim dalı tarafından yönlendirilen hasta ile birlikte doldurulup maruz kalınan ya da uygulanması planlanan etkenler ile ilgili literatür, teratojenite açısından ayrıntılı bir şekilde taranarak bir rapor hazırlanmıştır. Ayrıca, gebelik döneminde uygun olmayan ajanlar için güvenli seçenekler ile, gerekiyorsa laktasyon dönemi için planlanan ya da kullanılmış olan ilaçlarla ilgili bir değerlendirme de raporda yer almış, hasta uygun şekilde bilgilendirildikten sonra, rapor kendisine verilerek hekimine iletilmesi sağlanmıştır [53].

$\mathrm{Bu}$ işlev çerçevesinde, bireysel olarak hastalar için rapor hazırlamanın dışında, topluma ya da sağlık görevlilerine yönelik bilgilendirme seminerleri yapılmış ve hazırlanmış olan web sayfası aracılığıyla topluma yönelik bilgilendirme de sunulmuş, ayrıca konuyla ilgili araştırmalar da yürütülmüştür [53, 54].

HİZBİ'in resmi web adresi: http://www.hizbib.hacettepe.edu.tr

\section{Sonuç}

Teratojenite danışma servislerinin hamilelik ve emzirme dönemindeki riskler konusunda bilimsel danışmanlık hizmeti sunması, anne ve bebek sağlığ için yaşamsal öneme sahiptir. Belirli yönetmeliklere uygun olarak hizmet veren bu merkezler, her geçen gün bilgi birikimlerini artırmakta ve yeni açılan merkezlerle hizmet verilen saha genişlemektedir. Ancak yeterli olup olmadığ 1 devamlı sorgulanmalıdır. Hükümetler, sağlık bakım kuruluşları ve akademik kurumlar bölgelerinde bu tür hizmetlere olan ihtiyac1 araştırmalıdır.

Doğum kusurlarıyla ilgili bilgilerin net ve düzenli bir şekilde kaydedilmesi ve bu bilgilerin servisler arasında ve hekimlerle hızlı bir şekilde paylaşılması, bu konudaki bilgi yetersizliğini azaltmak açısından çok önemlidir. $\mathrm{Bu}$ bilgilerin elde edilmesinde verileri kullanılan gebeye, izlemin devamının bireysel ve toplumsal yararları anlatılmalı, verileri doğru bir çerçeve içinde değerlendirebilmek için gerekli izlem süresi tamamlanmalıdır.

Gebelikte ve emzirme yoluyla maruz kalınan riskler ve alınabilecek önlemlerle ilgili olarak, TBS'ler aracılığıyla bilgi sağlama konusundaki kamu sağlığı iyileştirmeleri, hem bireysel sağlık hizmeti hem de sağlık görevlilerinin hizmetlerini daha yetkin bir şekilde yürütmeleri konusunda büyük adımlar atılmasına katkıda bulunacaktır. 


\section{Teşekkür}

\section{Çıkar Çatışması}

Yazarlar finansal veya başka bir yolla çıkar çatışmaları olmadığını beyan ederler.

\section{Kaynaklar}

1. Kaplan YC, Karadaş B, Küçüksolak G, Ediz B, Demir Ö, Sozmen K, Nordeng H: Counselling pregnant women at the crossroads of Europe and Asia: effect of Teratology Information Service in Turkey. International Journal of Clinical Pharmacy. 2017, 39(4):783-790.

2. Duman MK. Türkiye'de Teratojenite Bilgi Servisleri. Türk Farmakoloji Derneği E-Bülteni. 2013, (62):2-5.

3- Mitchell AA, Gilboa SM, Werler MM et al. National birth defects prevention study. Medication use during pregnancy, with particular focus on prescriptiondrugs: 1976-2008. Am J Obstet Gynecol 2011;205(1):51-58

4. Olukman M, Parlar A, Orhan CE, Erol A: Gebelerde ilaç kullanımı: Son bir yıllık deneyim. Turkish Journal of Obstetrics and Gynecology. 2006, 3(4): 255-261.

5. Leen-Mitchell M, Martinez L, Gallegos S, Robertson J, Carey JC: Mini-review: History of organized teratology information services in North America. Teratology. 2000, 61(4):314-317.

6. Karakoc H, Uctu AK. Care and counseling of fetal health effects of preconceptional period maternal drug use. Biomedical Journal of Scientific \& Technical Research. 2018, 3(5):3596-3599.

7. Peters P, Miller RK, Schaefer C. General commentary on drug therapy and drug risks in pregnancy. In: Schaefer C, Peters $P$, Miller RK (eds). Drugs during pregnancy and lactation. 3rd Ed. Elsevier, Amsterdam, 2015: pp. 1-23.

8. Sarıkaya E, Çayırtepe Z: Gebelikte Farmakovijilans ve Teratojenite. 2019 Mayıs, TAÇESE Yayınları, Ankara

9. Niebyl, J, Simpson, J, Teratology and Drugs in Pregnancy. Global library of women's Medicine, May 2008

10. Clementi, M, Di Gianantonio, E. Clinical Teratology. In: Nicolopoulou-Stamati P, Hens L, Howard CV (Eds), Congenital Diseases and the Environment. Springer, 2007: pp. 147-160.

11. Vargesson N, Fraga L: Teratogenesis. In: eLS. Developmental Biology. John Wiley \& Sons, Ltd: Chichester. 2017: pp. 1-7. DOI: 10.1002/9780470015902.a0026056

12. Schaefer C. Drug safety in pregnancy: Utopia or achievable prospect? Risk information, risk research and advocacy in Teratology Information Services. Congenital Anomalies. 2011, 51(1):6-11.
13. Ergun Y: Teratolojik ilaçlara maruziyet ve risk analizi. Kahramanmaraş Sütçü İmam Üniversitesi Tıp Fakültesi Dergisi. 2016, 11(1): 37 - 48 .

14- Mazzu-Nascimento T, Melo DG, Morbioli GG, Carrilho E, Vianna FSL, da Silva AA, Schuler-Faccin L: Teratogens: a public health issue - A Brazilian overview. Genetics and Molecular Biology. 2017, 40 (2)

15. Zeynep Öztürk. İlaç kullanan gebeye yaklaşım: Teratojenite riski ve danışmanlık hizmeti. Sürekli Tıp Eğitimi Dergisi (STED). 2014, 23 (5): 201.

16. Özbudak, H, Ünal Z, Sabuncuoğlu, S. Gebelikte non-steroidal antiinflamatuvar ilaçların kullanımının değerlendirilmesi, Marmara Pharmaceutical Journal. 2016, 20:72-9.

17. Bánhidy F, Lowry RB, Czeizel AE: Risk and benefit of drug use during pregnancy. International Journal of Medical Sciences. 2005, 2(3):100-106.

18- Yıldız H, Abuaf OK. [Use of cosmeceuticals during pregnancy and lactation period]. [Turkderm-Archives Of The Turkish Dermatology And Venerology]. 2013; 47(4): 194-199.

19-American Botanical Council - The Commission E monographs. Erişim tarihi 2 Mart 2021. Erişim adresi http://cms.herbalgram.org/commissione/Monographs/Monograph0185.html. [İnternet]

20. European medicines agency: Herbal- European Union monographs and list entries. Erişim tarihi 10 Mart 2021. Erişim adresi https://www.ema.europa.eu/en/human-regulatory/herbal-products/european-union-monographs-list-entries [İnternet]

21. Clementi M, Gianantonio ED, Ornoy A. Teratology information services in Europe and their contribution to the prevention of congenital anomalies. Journal of Community Genetics. 2002, 5(1):8-12.

22. Miral M, Kızılkaya Beji N: Gebelikte ilaç kullanımı ve danışmanlık. Sağlık Bilimleri ve eslekleri Dergisi (HSP). 2017, 4(2):142-148

23. Cragan JD, Friedman JM, Holmes LB, Uhl K, Green NS, Riley L: Ensuring the safe and effective use of medications during pregnancy: planning and prevention through preconception care. Maternal and Child Health Journal. 2006, 10:S129-S135.

24. Dunlop AL, Jack B, Frey K: National recommendations for preconception care: The essential role of the family physician. Journal of the American Board of Family Medicine. 007, 20(1): 81-84.

25. Song I, Choi SH, Shin JY: Trends in prescription of pregnancycontraindicated drugs in Korea, 2007- 2011. Regulatory Toxicology and Pharmacology. 2016, 75: 35-45.

26. Lechat MF, Dolk H. Registries of congenital anomalies: EUROCAT. Environment Health Perspectives. 1993, 101 (Suppl 2):153-157. 
27. Boyd PA, Haeusler M, Barisic I, Loane M, Garne E, Dolk H. The EUROCAT Network-Organization and processes. Birth Defects Research Part A: Clinical and Molecular Teratology. 2011, 91(1):2-15.

28. EUROCAT: Erişim tarihi 11.Ocak.2021. Erişim adresi: https:// eu-rd-platform.jrc.ec.europa.eu/eurocat/eurocat-members/registries_en [İnternet]

29. Dolk H: EUROCAT: 25 Years of European surveillance of congenital anomalies. Archieves of Diseases in Childhood Fetal \& Neonatal Edition. 2005, 90(5):F355-358.

30. Mother to Baby-The Organization of Teratology Information (OTIS): Erişim tarihi: 22 Kasım 2020. Erişim adresi: https:// mothertobaby.org/about-otis/. [İnternet]

31. Addis A, Sharabi S Bonati M: Risk classification systems for drug use during pregnancy. Are they a reliable source of information? Drug Safety. 2000, 23 (3): 245-253

32. Feibus KB: FDA's proposed rule for pregnancy and lactation labeling:1mproving maternal child health through wellinformed medicine use. Journal of Medical Toxıcology, 2008, 4 (4): 284-288.

33. Federal Register: Food and Drug Administration. Pregnancy, lactation, and reproductive potential: Labeling for human prescription drug and biological products - content and format: Guidance for industry. 2014. Erişim tarihi 3 Mart 2021. Erişim adresi https://www.federalregister.gov/documents/2008/05/29/E8-11806/content-and-format-of-labelingfor-human-prescription-drug-and-biological-productsrequirements-for, [İnternet]

34. Kaplan YC, Can H, Demir Ö, Karadaş B, Yılmaz İ, Temiz TK: İlaçların gebelikte kullanımlarına dair risk iletişiminde yeni dönem: FDA gebelik risk kategorileri değişiyor. Türkiye Aile Hekimliği Dergisi. 2014, 18(4):195-198

35. Karahalil B: Prenatal donemde ilac kullanımı ve teratojenite riski. Türkiye Klinikleri Medical Genetics-Special Topics Archieve. 2018, 3(1):97-108.

36. Roca C: An Evolution of Labeling Information for Pregnant Women: PLLR History and Background. Erişim tarihi 4 Mart 2021. Erişim adresi https://www.fda.gov/files/advisory\%20 committees/published/An-Evolution-of-Labeling-Informationfor-Pregnant-Women--PLLR-History.pdf, [Internet]

37. Food and Drug Administration. Pregnancy, lactation, and reproductive potential: Labeling for human prescription drug and biological products - content and format: Guidance for industry. July 2020. Erişim tarihi 7 Mart 2021. Erişim adresi https://www.fda.gov/regulatory-information/search-fdaguidance-documents/pregnancy-lactation-and-reproductivepotential-labeling-human-prescription-drug-and-biological [İnternet]
38. Australian Drug Categories: Erişim tarihi 11 Aralık 2020. Erişim adresi: https://embryology.med.unsw.edu.au/embryology/ index.php/Australian_Drug_Categories. [İnternet]

39. Schwarz EB, Santucci A, Borrero S, Akers AY, Nikolajski C, Gold MA: Perspectives of primary care clinicians on teratogenic risk counseling. Birth Defects Research Part A-Clinical and Molecular Teratology. 2009, 85(10):858-863.

40. Friedman JM, Weber-Schöndorfer C. Antineoplastic drugs. In. Schaefer C, Peters P, Miller RK (eds). Drugs during pregnancy and lactation. 3rd Ed. Elsevier, Amsterdam, 2015: pp. 373-399

41. Chambers C: The role of teratology information services in screening for teratogenic exposures: challenges and opportunities. American Journal of Medical Genetics-Seminars in Medical Genetics. 2011, 157C(3):195-200.

42. Felix RJ, Jones KL, Johnson KA, McCloskey CA, Chambers $\mathrm{CD}$ : Postmarketing surveillance for drug safety in pregnancy: The Organization of Teratology Information Services project. Birth Defects Research Part A-Clinical and Molecular Teratology. 2004, 70(12):944-947.

43. Hancock RL, Koren G, Einarson A, Ungar WJ: The effectiveness of teratology Information Services (TIS). Reproductive Toxicology. 2007, 23(2):125-132.

44. Kaplan YC, Kelekçi S, Demir Ö: Gebelikte ilaç maruziyeti sonrasında risk değerlendirmesi, risk iletişimi ve perinatal değerlendirme. Nobel Medicus. 2015, 11(1):14-21.

45. Garbis JM, Robert E, Peters PW: Experience of two teratology information services in Europe. Teratology. 1990, 42(6):629634.

46. Demir R, Taşpınar A: Gebelikte akılcı ilaç kullanımı. Arşiv Kaynak Tarama Dergisi. 2019, 28(3):193-200.

47. Hales BF, Robaire B. Paternal exposure to drugs review and environmental chemicals: Effects on progeny outcome. Journal of Andrology. 2001, 22 (6): 927-936.

48. Engeland, A., Bjørge,T., Kjersti Daltveit, A., Skurtveit, S., Vangen, S., Vollset, S. E., Furu, K: Effects of preconceptional paternal drug exposure on birth outcomes: Cohort study of 340000 pregnancies using Norwegian population-based databases. British Journal of Clinical Pharmacology, 2012, 75(4): 1134-1141.

49. De Santis M, Cesari E, Cavaliere A, Ligato MS, Nobili E, Visconti D, Caruso A: Paternal exposure and counselling: Experience of a Teratology Information Service. Reproductive Toxicology. 2008, 26(1):42-46.

50. Dokuz Eylül İlaç ve Zehir Danışma Merkezi: Erişim Tarihi 3 Mayis 2020.

Erişim adresi: http://web.deu.edu.tr/zdm/tr/index_dosyalar/ page0001.html. [İnternet]. 
51. T.C. Resmi Gazete. Karadeniz Teknik Üniversitesi Teratojenite Araştırma ve Uygulama Merkezi (TAUM) Yönetmeliği. 15.06.2015. Sayı:29387, Başbakanlık Basımevi, Ankara.

52. İzmir Kâtip Çelebi Üniversitesi: Erişim Tarihi 3 Mayıs 2020. Erişim adresi: https://terafar.ikcu.edu.tr/S/15320/hakkimizda. [İnternet].

53. Hacettepe İlaç ve Zehir Bilgi Birimi: Erişim Tarihi 3 Mayıs 2020. Erişim adresi: $\quad$ http://www.hizbib.hacettepe.edu. tr/tr/menu/hizbib_hakkinda-1. [İnternet].

54. Çeliker A, Özdemir N: Retrospective analysis of Hacettepe Drug and Poison Information Unit -Teratogenicity Consultancy Services (HIZBIB-TDS)' data about drug use in pregnants. 12nd International Symposium on Pharmaceutical Sciences (ISOPS), 26-29 Haziran 2018, Ankara. pp: 41-42. 